\title{
Participation of the Military Gendarmerie in the Fight against Terrorism
}

\begin{abstract}
The article describes the most importnant tasks and competence of the Military Gendarmerie in the field of fighting against terrorism in Poland as well as during military missions. Special space of the article was dedicated to élite units which are the MG Specialized Units. Addictionally, the author presents the scope of co-operation of Military Gendarmerie with other services.
\end{abstract}

Keywords: mediatization, discourse, public sphere, political science, mass media

One of the key subjects in maintaining national security is the Polish Army, especially considering asymmetric threats and, most of all, terrorism. A significant role is played by the military intelligence and counterintelligence, special forces, security forces and specialized services of the Polish Armed Forces in the form of the Military Gendarmerie.

The "National Anti-Terrorism Programme for 2012-2016" states that "In the context of the subject matter of the Programme, an important role is played by the Military Gendarmerie, which is a specialized service of the Polish Armed Forces. The competences of the MG include, among others, ensuring the protection of public order on military areas and military installations as well as in public places and performing protective activities towards authorized persons. During the realization of the abovementioned tasks MG cooperates with Polish and foreign authorities and services competent in matters of security and public order and military polices" .

The tasks of the Military Gendarmerie include:

- ensuring adherence to military discipline;

1 Narodowy program antyterrorystyczny RP na lata 2012-2016, p. 14. 
- protecting public order on military areas and military installations as well as in public places;

- protecting life and health of humans and military property against incidents violating these goods;

- preventing persons referred to in Article 3 Paragraph $2^{2}$ from committing crimes and offences and other pathological phenomena, especially: alcoholism and drug addiction in the Armed Forces;

- cooperating with the Polish and foreign authorities and services competent in matters of security and public order and military polices;

- combating natural disasters, extraordinary threats to the environment and eliminating their effects as well as actively participating in search and rescue operations and humanitarian actions aimed at protecting life and health of humans and property ${ }^{3}$.

Moreover, Military Gendarmerie, due to the changing threats including terrorism and organized crime, realizes tasks according to the amended Act on the Police (JL of 2002 No. 43, item 277 as amended). Article 18a of the Act states:

"1. In case of threat to safety and public order, if the Police forces are insufficient to perform their tasks of safety and public order protection, the President of the Council of Ministers, upon request of the Minister competent for internal affairs, following consultation with the Minister of National Defence, may order the use of soldiers of Military Gendarmerie to provide assistance to the Police.

2. In case referred to in Paragraph 1, soldiers of the Military Gendarmerie are entitled, in the scope necessary to perform their tasks, towards all persons, to the same authorisations as the police officers, defined in Articles 15-17. The exercise of such authorisations shall be based on the principles and under procedures defined for police officers"'.

The tasks of the Military Gendarmerie in assisting the Police could include:

- operational and exploratory activities and procedural steps within their competences;

- prevention, investigation, detection, securing places, facilities and areas, including access control and securing places important for national security;

- isolating the scene, setting up traffic detour, checkpoints and blockade checkpoints and patrolling the area;

2 Paragraph 2 refers to soldiers not on active duty who wear uniforms and military emblems and badges.

3 Ustawa z dnia 24 sierpnia 2001 r. o Żandarmerii Wojskowej i wojskowych organach porządkowych (tekst jednolity), JL of 2013 item 568 as amended.

4 Ustawa z dnia 6 kwietnia 1990 r. o Policji, JL of 2007 No. 43, item 277 as amended. 
- special protection of people;

- combating terrorism in a physical manner 5 .

The Military Gendarmerie in performing its tasks cooperates with the civil authorities at the central and local levels as well as the Border Guard, the State Fire Service, the General Customs Inspector, the General Inspector of Treasury Control, the Government Protection Bureau, the Internal Security Agency ${ }^{6}$ and the Military Intelligence Service and the Military Counterintelligence Service?

The structure of the Military Gendarmerie is as follows: the Headquarters and the MG local organizational units (these are: 10 branches, 2 departments and 45 posts). Additionally, there are 2 MG Specialized Units established in $2004^{8}$.

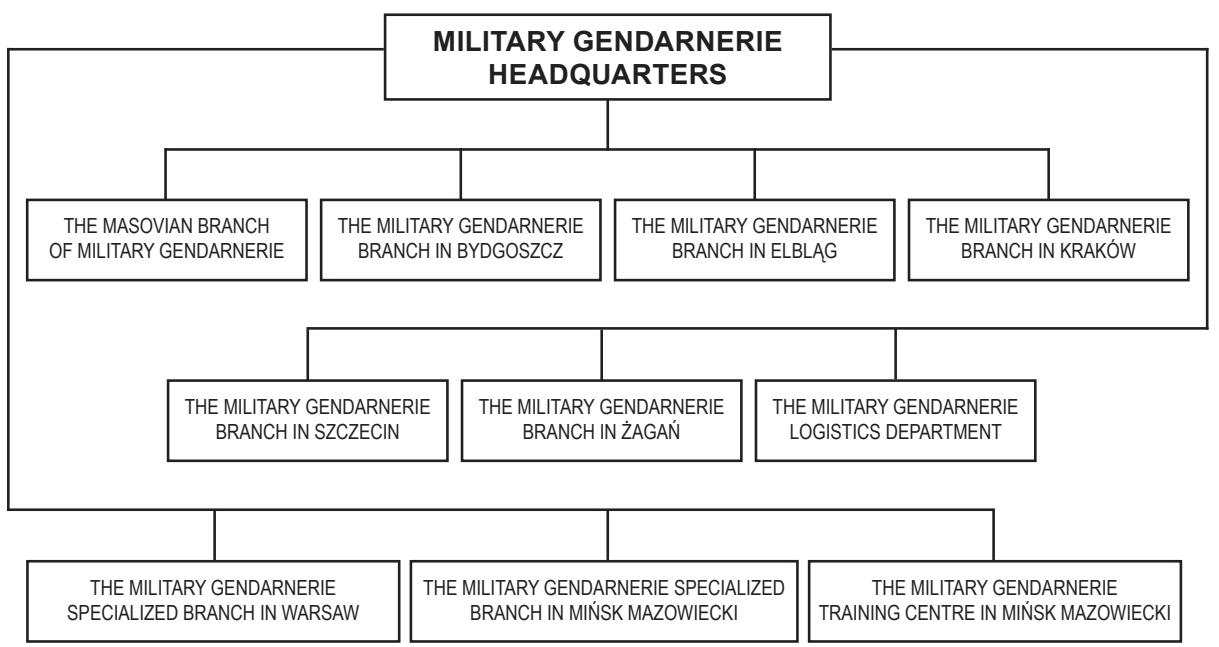

Source: http://www.zw.wp.mil.pl/en/206.html, (access 16.07.2014).

In terms of countering terrorism, Specialized Units are the most important. They are composed of:

1. Administration,

5 M. Witczak, Podstawowe zadania Żandarmerii Wojskowej, [in:] Przeciwdziałanie zagrożeniom niemilitarnym. Zasadnicze aspekty wspótpracy Żandarmerii Wojskowej i Policji, Legionowo 2009, p. 21.

6 B. Szmulski, Żandarmeria Wojskowa, [in:] Instytucje Bezpieczeństwa Narodowego, eds. M. Paździor, B. Szmulski,Warszawa 2012, p. 195.

7 Rozporzadzenie Ministra Obrony Narodowej z dnia 24 lipca 2012 r. w sprawie zakresu i trybu wspótdziatania Żandarmerii Wojskowej ze Stużba Kontrwywiadu Wojskowego, Stużbą Wywiadu Wojskowego, wojskowymi organami porzadkowymi oraz z dowódcami jednostek wojskowych i dowódcami (komendantami) garnizonów, JL of 2 August 2012.

8 The third MG specialized unit was disbanded in 2011 and Military Unit AGAD was formed on its basis. 
2. General Department,

3. Security Department,

4. Special Action Department,

5. Section for Protective Transport,

6. Section for Pyrotechnic and Radiological Reconnaissance?.

Among the tasks of the MG Specialized Unit in Warsaw are antiterrorist actions and special protection. The MG Specialized Units can be compared to the Government Protection Bureau, and thus they are responsible for the protection of the heads of the Ministry of the National Defence and also the President, Prime Minister, Speakers of the Sejm and the Senate during their visits to military units ${ }^{10}$.

The MG Specialized Units also perform the following tasks:

- counteracting land and air terrorist attacks;

- eliminating the effects of epidemics and counteracting biological, radiological and chemical terror ${ }^{11}$.

The MG Specialized Unit in Minsk Mazowiecki is dedicated to manoeuvring operations (it can be placed between prevention and storm sub-units). Its key task is to provide police support for the Polish Armed Forces units participating in missions, to support units and sub-units of the Armed Forces and the forces of the Ministry of the Interior and Administration (e.g. the Government Protection Bureau), that combat terrorism, protect facilities, prevent natural disasters and eliminate their effects. An important role is also providing police support to the allied forces remaining on the RP territory within the Host Nation Support assistance ${ }^{12}$.

The Military Gendarmerie, apart from supporting the Police during counterterrorist actions on the territory of Poland or securing military installations, participates in stabilization and peacekeeping missions on the territories with terrorist activity - such as Afghanistan. The latter tasks are performed by the soldiers of the MG Specialized Units due to their equipment and training. Their tasks include:

- ensuring control of the area of the contingent's activity through, for example, patrolling, reconnaissance and monitoring of the local situation;

- training local police forces;

- conducting interventions;

9 Zarzadzenie Nr 52/MON Ministra Obrony Narodowej z dnia 22 września 2003 r. w sprawie utworzenia specjalistycznej jednostki organizacyjnej Żandarmerii Wojskowej, JL MND of 17 October 2003.

10 Zadania OS ŻW, see: http://www.oszw.warszawa.wp.mil.pl/, (accessed 16.07.2014).

11 Ibidem.

12 OSŻW w Mińsku Mazowieckim, see: http://www.zw.wp.mil.pl/pl/156.html, (accessed 16.07.2014). 
- convoying and protecting special cargo;

- providing security measures to the VIPs;

- inspecting persons, places and buildings13.

In extreme cases soldiers of the MG Specialized Units can be deployed in offensive actions to eliminate terrorist threat. The Military Gendarmerie cooperates also with other forces - such as the Air Forces or the Chemical Forces ${ }^{14}$.

The Military Gendarmerie, on the account of the changing nature of threats and the engagement of Poland in counterterrorist actions, needed a transformation of training and equipment, which was particularly successful in the case of specialized units, where soldiers undergo specialist trainings on action in urban terrain, both protective and offensive, while the Gendarmerie itself became an important element of the Polish system to combat terrorism.

13 Ibidem.

14 B. Pacek, Sity Zbrojne RP w walce z terroryzmem, [in:] Wojna z terroryzmem $w$ XXI wieku, eds. B. Hołysta, K. Jałoszyński, A. Letkiewicz, Szczytno 2009, p. 299. 